\title{
Perception of Youth on Reproductive Health in Boarding La Tansa in 2021 \\ ${ }^{1}$ Elsya Zaina Elidzar, ${ }^{2}$ Himmatul Ulya, ${ }^{3}$ Mega Rizki Utami, ${ }^{4}$ Munaya Fauziah \\ ${ }^{1,2,3,4}$ Faculty of Public Health, Muhammadiyah University of Jakarta \\ K.H Ahmad Dahlan St, Cirendeu, Ciputat, South Jakarta, 15419 \\ E-mail: megarizky99@gmail.com
}

\begin{abstract}
The problems of health reproduction adolescents in Indonesia caused not optimal commitment and support of the government in the form of a policy that is set on the education of sexual and reproduction for adolescents in order of family, community, and school. To continue the struggle of the nation, it is hoped that youth have ethics and morals that are responsible for the good.This study aims to determine Adolescent Perceptions of Reproductive Health in students at the La Tansa Islamic Boarding School. The research method used is qualitative research with in-depth interviews. Informants will be conducted in-depth interviews are three informants students teenage daughter at Pondok Pesantren La Tansa. The results of the study showed that the discussion about health reproduction is not a thing taboo to talk about. In the handling of all the problems of health reproduction usually with medication to the doctor or even just be left alone (in the case of vaginal discharge ), but seldom of them that experience interference health reproduction. A sense of shame and is still considered taboo became one of the factors that did not perform the treatment when it occurs the problem. Many once the benefits that will be obtained when held counseling about health reproduction, but the media are used also should be expected to make the students understand to be things about the health of reproduction it alone. To conduct counseling health cottage boarding they rarely conduct outreach on the topic of this, in addition to the situation of a pandemic covid-19 now makes counseling difficult to do because be no crowd. Based on the results of the analysis and discussion of the research is that the perception of adolescents about health reproduction in Pondok Pesantren La Tansa year 2021 is still low because of lack of knowledge of teen-related health reproduction in pond ok boarding it.
\end{abstract}

Keywords: Reproductive Health, Perception, Adolescents.

\section{INTRODUCTION}


Adolescents are one of the parts of the source of the power of man and the future ahead of the nation. As a next-generation successor to the nation, teens will play a role important in the continuing development of the nation Indonesia and helped contribute largely in determining the fate of the nation.

To continue the struggle for the nation are expected to teens have ethics and morals that are responsible for the good. Conversely which becomes a threat great if the teen is not fostered by good, will give rise to various problems serious as what happened when these. Issues are among others the abuse of drugs, delinquency juvenile, and including issues that relate to the activity of sex, such as harassment and abuse sexual, relationship sexual pre-marriage, unwanted pregnancy (Pregnancy Not Preferred), abortion, marriage at the age of young, PMS (Disease Transmitted Sexually) including HIV / AIDS as well as the problems of social others are very influential on the readiness of teenagers to meet future ahead.

The knowledge of the health of reproduction in adolescents themselves was not adequate that can be seen by only $35.3 \%$ of adolescent girls and $31.2 \%$ of adolescent males aged 15-19 years know that women can be pregnant with a time -related sexual. Similarly, the symptoms of PMS are less known by teenagers. Information about HIV is relatively more lots accepted by adolescents, although only $9.9 \%$ of adolescent girls and $10.6 \%$ of men knew comprehensively about HIV-AIDS. (1)

Perceptions of each individual are influenced by several factors. According to Ben Walgito, two factors are influence perception among others: factors internal and factors external. Factors internal are factors that exist within the individual's own, like the feeling, the experience, the ability to think, and the frame of reference. While the factor of external is a factor of the stimulus it alone and factors environment where perception was underway. Although the stimulus is the same if the situation of social the underlying stimulus person is different then a different result perception (Slamento in Setiwati, 2010).

Problems related to sexuality and reproductive health are still faced by many teenagers. The issues are among others such as rape, free sex, Pregnancy Not Wanted (KTD), abortion, marriage, and pregnancy early. (3)

\section{METHODS}

The research is aimed at for know the Perceptions of Youth Against Health Reproduction on students. The type of research is that qualitative by using the approach to the design of triangulation samples to determine Perceptions of Youth Against Health Reproduction on students. Research is carried out to the teen daughter of students cottage boarding La Tansa, Lebak, Banten with the retrieval of data through interviews depth using guidelines for the interview. 
The method of research that is used is to use the type of research qualitative with interview depth that aims to know the perception of Teens Against Health Reproduction on students in Pondok Pesantren La Tansa year 2021.

The source of information or informants in this study was a young female student. Retrieval of samples is done online via telecommunications to avoid contact during a pandemic lasts. Informants who will do interviews depth is 3 people informant that the status of students teenage daughter who exists in Pondok Pesantren La Tansa, Lebak, Banten. Informants were selected based on special characteristics by the research objectives.

Table 1. List of Informant Data

\begin{tabular}{cccc}
\hline $\begin{array}{c}\text { Initials } \\
\text { Informant }\end{array}$ & Age & $\begin{array}{c}\text { Type } \\
\text { Sex }\end{array}$ & Profession \\
\hline ZW & 14 & $\mathrm{P}$ & Student \\
\hline SW & 16 & $\mathrm{P}$ & Student \\
\hline $\mathrm{I}$ & 17 & $\mathrm{P}$ & Student \\
\hline
\end{tabular}

There are two types of data sources used in this study, namely primary data and secondary data. Primary data was obtained from the results of observation directly in the field with the questions that appropriate guidelines for interviews about knowledge health reproduction with interviews depth while the data secondary obtained from journals that relate to research this.

The validity of the data is done by the method of triangulation source and triangulation methods done by using interviews depth to the informant who has been determined by using the instruments of research in the form of guidelines for the interview. Method triangulation is done using in-depth interviews and observation of data from literature studies. Researchers use this triangulation to ensure the accuracy of the data collected depth interviews and observation of data from literature studies. Researchers use this triangulation to ensure the accuracy of the data collected.

Studies have received permission from the lecture Methods Research Qualitative Public Health University Muhammadiyah Jakarta. The interviewer gives research information is through a cell phone before doing interviews and informants give consent verbally before the interview. Interviews were recorded, and information right, shipped and recorded. The transcript of the interview is anonymized, as well as the analysis and interpretation of data/presentation.

Processing and analysis of data qualitative in research are carried out by stages transcript of data where the data was transferred in the form of writing is complete without a change, add, or reduce the information that there is in recording such. Then an analysis of the data is descriptive so obtained conclusions from data that has been processed to perform coding on each answer informant. The result is illustrated in Table 2 . 


\section{RESULTS AND DISCUSSIONS}

Characteristics of Respondents The research was conducted with respondents as much 3 people aged 14-17 years.

\section{Table 2. Results of Data Analysis}

\begin{tabular}{|c|c|c|c|c|c|c|}
\hline No & Topic & Meaning Unit & Code & Sub Category & Category & Theme \\
\hline 1. & \multirow[t]{3}{*}{$\begin{array}{l}\text { What do } \\
\text { you know } \\
\text { about } \\
\text { Reproductiv } \\
\text { e Health? }\end{array}$} & $\begin{array}{l}\text { Organ reproduction } \\
\text { we were healthily } \\
\text { spared from various } \\
\text { kinds of diseases. }\end{array}$ & $\begin{array}{l}\text { The } \\
\text { health of } \\
\text { the } \\
\text { reproduct } \\
\text { ive } \\
\text { organs is } \\
\text { protected } \\
\text { from dise } \\
\text { ase }\end{array}$ & $\begin{array}{l}\text { The meaning of } \\
\text { reproductive } \\
\text { health }\end{array}$ & \multirow{3}{*}{$\begin{array}{l}\text { Reproductive } \\
\text { health knowledge }\end{array}$} & \multirow{3}{*}{$\begin{array}{l}\text { Health } \\
\text { Reproductive }\end{array}$} \\
\hline & & $\begin{array}{l}\text { Keeping Healthy repr } \\
\text { oduction is a thing } \\
\text { that is very } \\
\text { important for the } \\
\text { adolescent. Because } \\
\text { the teenager is } \\
\text { a time that is best to } \\
\text { do a habit that good. }\end{array}$ & $\begin{array}{l}\text { Maintaini } \\
\text { ng } \\
\text { the health } \\
\text { of reprod } \\
\text { uctive or } \\
\text { gans whe } \\
\mathrm{n} \text { it is } \\
\text { important }\end{array}$ & $\begin{array}{l}\text { Health organs of } \\
\text { reproduction } \\
\text { Health } \\
\text { productive }\end{array}$ & & \\
\hline & & $\begin{array}{lr}\text { Our } & \text { healthy } \\
\text { reproductive } & \text { organs } \\
\text { are protected } & \text { from } \\
\text { various kinds } & \text { of } \\
\text { diseases. } & \end{array}$ & $\begin{array}{l}\text { Health } \\
\text { tool } \\
\text { reproduct } \\
\text { ion spare } \\
\text { d from di } \\
\text { sease }\end{array}$ & $\begin{array}{l}\text { Health } \\
\text { Reproductive }\end{array}$ & & \\
\hline
\end{tabular}

Table 3. Synthesis of Data Analysis Results

\begin{tabular}{|c|c|c|}
\hline Theme & & Reproductive Health \\
\hline Category & & Reproductive Health Knowledge \\
\hline \multirow[t]{2}{*}{ Sub Category } & Mean & Reproductive Health \\
\hline & Reproductive Health & Reproduction \\
\hline Code & $\begin{array}{l}\text { The health of } \\
\text { the reproductive organs is prot } \\
\text { ected from disease }\end{array}$ & $\begin{array}{l}\text { Maintaining the health of Health tool reproduction spared fr } \\
\text { reproductive organs when it om disease } \\
\text { is important }\end{array}$ \\
\hline
\end{tabular}

Knowledge about reproductive health is very important for adolescents. The media has great potential in changing people's attitudes and behavior, especially children who are still relatively affected and influenced (4).

Based on the results of interviews with informants about knowledge about the meaning of reproductive organs and reproductive health, the following are the results of the interviews :

" Organ parts inside and outside the body that can be in view is directly or not directly" (I, 17 Years ). Same as with students more: 
"The organ that used to come out of her the blood of menstruation, to give birth, to relate intimately and so forth" (WH, 14 years ).

The same thing was also expressed by this one informant, "The organs of the body that serves as a point of developing breeding to produce offspring” (SW, 17 years ).

Based on some of the statements above further indicates that the said organs of reproduction have always been associated by a teenager with the organs of the body that serves as to produce offspring. When teenagers hear the word organs of reproduction tend to think like that when it's mean very spacious.

According to the answers of female students regarding the meaning of reproductive health, namely: " About something that concerns the health of sexual and education sexual " ( SW, 16 years ).

" Keeping Healthy reproduction is a thing that is very important for the adolescent. Because the teenager is a time that is best to do a habit that good " (I, 17 years ).

"Organ reproduction we were healthy spared from various kinds of diseases" (WH, 14 years ).

Knowledge informant about the disruption of health was associated health reproduction on essentially everything is almost the same, and there are also among those who only know of a few only of nuisance disease are associated with health reproduction.

"Presence of disease: HIV, STI, Cervical Cancer" (SW, 16 years old ).

"uterine cancer, cervical cancer, menstrual disorders, ovarian cancer, and vaginal infections " (I, 17 years ).

"The presence of a disease or disorder in a tool reproduction are like cancer Rahim, whiteness" (WH, 14 years ).

If you are experiencing interference on health reproductive what that would informant in overcoming things that,

" Treating them to a doctor specialist, prevent the stay away from drugs, the relationship sexual be free" (SW, 16 years ).

Knowledge of students about the interruption of health reproduction of the results of the interview that among the many diseases of reproduction that exist, the most they know just cancer of the uterus, As for the others who mentioned is like gonorrhea, herpes, HIV, hepatitis, infertility, Ambien, itching, whiteness, and homosexual.

Provision of guidance and information on issues of health reproductive teenager told the students to do it routinely expected would give effect and increase in knowledge about health reproduction adolescent students will avoid things negatively or can overcome the problems in the 
organs of reproduction later that disturb the health of the reproductive and students will be spared from all kinds of diseases are associated with reproduction.

Problems of health reproduction adolescents in Indonesia caused not optimal commitment and support of the government in the form of a policy that is set on the education of sexual and reproduction for adolescents in order of family, community, and school. Customary norms and ancestral cultural values that are still adhered to by the majority of Indonesian people are also still an obstacle in the implementation of ommunity -based sexual and reproductive education, especially in schools Groups of adolescents that require attention are special by the practitioner's health, especially the nursing community (Stanhope \& Lancaster, 2004 in (5).

As for how the way to maintain the health of reproduction is to maintain the hygiene of the organs of reproduction. Such as that spoken by some informants.

Results of interviews with students :

" Clean the vagina every wastewater little and wastewater big, replace the pant in 2 times in a day, in addition to it also by exercising " (SW, 17 years ).

" D ith attention to the cleanliness of the apparatus of reproduction, put soap when cleaning $i t$, reducing use the pembalut at the time of menstruation and pay attention to the pattern of eating and multiply drinking water white and Changing pants in three times in a day " (I, 17 years ).

" Every once wastewater small then washes or rinse the vagina to clean, not only flushing water alone but need to be wiped/washed by hand and one day replace 2 times pants in (each bath)" (ZW, 14 years ).

In maintaining reproductive health, does the informant use products or tools to clean the reproductive organs. As the question above, the answers to some informants were spoken.

" money water little use water alone bu if more showers and wastewater big new clean up using soap " (SW, 17 years ).

" Usually using soap bath" (I,17 years ).

"Using bath soap and soaking in water" (ZW, 14 years old ).

Faisal (2009) in his research said that in fact, discussing the problem of education of health reproduction among cottage boarding certainly not the case that alien again. Because, not a few verses and hadiths and the thoughts of scholars related to this are studied in the yellow books, especially fiqh books, which are the scientific basis of Islamic boarding schools. The science of fiqh provides guidance, instructions, guidance, knowledge, and values on how a Muslim should behave and make decisions related to reproductive health (6).

Source education sex was used by teenagers generally be in the form of media mass both media print such as newspapers, magazines, and books and media electronics such as television and the Internet as well as friends peer or peer group. When this, a teenager a lot to get information 
and knowledge of the sex of the media mass and a friend the same age as the source of education that can provide information and knowledge in an open and transparent on them.

To be able to receive the information that is given, either it in the forum or Kah outside the forum, the thing that needs to be considered is the model of provision of information.

Results of interviews with students :

" Can using PowerPoint or poster" (SW, 16 years ).

"Before holding of seminars or gave an idea at the time described and no session discussion after held seminar or seminar " (I, 17 years ).

" Held counseling reproductive health with a picture or visual " (ZW, 14 years ).

Based on the answers of informants, so those female students can understand what was described then at the time of delivering the material broadcast video animation or displaying posters.

\section{CONCLUSIONS AND SUGGESTIONS}

Because it we recommend to the students to add to the knowledge they are to look for the source of knowledge related to health reproduction through sources other and has advised the leadership of schools to be made the agenda related to the health of reproduction so that the students gain knowledge that is more related to the health of reproduction.

\section{REFERENCES}

1. Ellysa. Adolescent Reproductive Health Situation. Adolescent Reproductive Health Situation. 2017.

2. Setiwati D. ADOLESCENT PERCEPTIONS ON SEX EDUCATION (Study. Universitas Sebelas Maret; 2010.

3. Aisyaroh N. ADOLESCENT REPRODUCTIVE HEALTH. 2015;

4. Hidayati L, Dainy NC, Rohmatullayaly EN, Briawan DD. YOUTH PERCEPTIONS ABOUT REPRODUCTIVE HEALTH, PREGNANCY AND MARRIAGE IN Adolescents: A QUALITATIVE STUDY ON RURAL AND URBAN HIGH SCHOOL STUDENTS Students of Postgraduate Human Nutrition Studies Program IPB 3 Students of Postgraduate Animal Bioscience Study Program IPB 4 Lecturer of the Department of Community Nutrition FEMAIPB. J Health. 2013;6(1):58-71.

5. Susanto T, Rahmawati I, Sulistyorini L. Youth Corner: Efforts to Improve Reproductive Health Skills. J Nursing. 2015;3(2):246-55.

6. Halima, Raman R. Adolescent Perceptions About Reproductive Health at the Islamic Boarding School Manahilil Ulum Hidayiah Kaballangan Pinrang Regency J Masy Health. 2014;3(9):41-7. 
Volume I Tahun 2021

November 2021
E-ISSN: 2808-5361

http://e-journal.fkmumj.ac.id/
Proceeding The First Muhammadiyah InternasionalPublic Health and Medicine Conference 